\title{
'Shakestivalling' in the New Europe
}

\section{Nicoleta Cinpoeş}

\begin{abstract}
This article maps out the landscape of Shakespeare festivals in Europe and argues that the European Shakespeare Festivals Network (ESFN) has been crucial to putting them on the Shakespeare tourist map. ESFN is a cultural foundation established in March 2010 as an association of five Shakespeare festivals: Bath (United Kingdom), Craiova (Romania), Gdańsk (Poland), Gyula (Hungary), and Neuss (Germany). This article begins with documenting the Network's first ten years of activity (as yet not attempted) in a survey of its member festivals. The second part of this article offers potential directions for a broader exploration of European Shakespeare festivals as a phenomenon in its own right, as a form of Shakespeare tourism, with a place in the broader field of Shakespeare studies.
\end{abstract}

\section{Key words}

festivals, Shakespeare, ESFN, tourism, 'Shakestivalling' 
Shakespeare festivals in the English-speaking world have become tourist shrines in their own right, as Robert Ormsby argues when discussing Stratford-upon-Avon and the London Globe (ORMSBY 2017). Though they have been the focus of critical attention in regular reviewing by specialist journals, ${ }^{1}$ Shakespeare festivals on continental Europe are a comparatively more recent addition to the global tourist circuit and a relatively new topic of research in Shakespeare studies. ${ }^{2}$ As the first of its kind, my article begins with charting the activity of a European network that has enabled 'Shakestivalling', a term I have coined for this particular form of Shakespeare production and tourism generated through Shakespeare festivals. Following a very brief, retrospective historical survey of the different festivals in the European Shakespeare Festival Network, I offer perspectives for future consideration as to theoretical approaches to festivals to suggest potential directions in generating a conceptual framework for analysing European Shakespeare festivals as distinct both from other types of theatre festivals ${ }^{3}$ and from North-American Shakespeare festivals ${ }^{4}$, which have long and rather different traditions.

\section{In the beginning ...}

Since its inception, the Network (set up as a Foundation, i.e., a registered charity) has been an organisation open to interest in all things Shakespeare. As its six key goals outline, ESFN focuses on (1) festivals 'especially in the cities and countries which are the seats of the Founders' but also on (2) promoting Shakespeare's works in the theatre and other media, (3) 'common educational, scholarly, popularising actions', (4) shared 'artistic initiatives' such as productions of Shakespeare's works, and (5) supporting the work of 'artists, translators and scholars' along with organising (6) 'conferences and scholarly sessions related to the theatre and the works of Shakespeare' (ESFN 2010: 1-2). ${ }^{5}$ In practice such ambitious aims have meant members joining efforts to create a European Shakespeare powerhouse, complete with its own periodical and database that archive the busy calendar of events and activities of ESFN.

Open from the very beginning to interested festivals and initiatives from the continent as well as beyond, who simply need to apply to join, the Network advertises itself

1 See, for example, Maria Shevtsova's work $(2012,2013,2014,2016)$ in the New Theatre Quarterly and the increased interest Cahiers Élisabéthains has been paying to Shakespeare festivals (e.g., VALLS-RUSSELL and ABELLA 2009; MARCH and VALLS-RUSSELL 2016; CINPOEŞ and VALLS-RUSSELL 2019a, b).

2 Indeed, the first collective volume on Shakespeare festivals on the continent as a phenomenon in Shakespeare studies is currently in the making under the editorial efforts of Nicoleta Cinpoeş, Florence March, and Paul Prescott (forthcoming with Bloomsbury in 2022).

3 There has been growing attention to theatre festivals in the past few decades; the acknowledgement of this phenomenon as a field of research in its own right has culminated in the latest release (KNOWLES 2020).

4 See, for example, (ENGLE et al. 1995), as well as the online databases https://www.nosweatshakespeare. com/festivals/ and https://www.playingwithplays.com/shakespeare-educational-resources/shakespearefestivals/.

5 I gained access to the document courtesy of Joanna Sniezko, ESFN liaison contact. 
as 'a unique opportunity [...] to exchange information and experience, participate in common projects, and mutually inspire each other for future ventures' (ESFN 2021). Serving 'as a platform for dialogue and innovation in the promotion and development of Shakespeare festivals and initiatives' (ESFN 2021), ${ }^{6}$ the Network has also grown to mean access to European subsidies and grants for individual and partnership ventures in an attempt to create a lifeline for the financially starved world of arts and theatre in candidate or future-candidate countries seeking to join the European Union and other countries of the former Eastern Bloc. ${ }^{7}$

Last but by no means least, outreach has been on the Network's agenda not only as a buzzword that looks good on grant applications, but as a shared commitment to the respective local and/or regional communities, and especially reaching the otherwise underprivileged and socially excluded members of these populations. ${ }^{8}$

\section{Ten years on}

Within a decade of activity, ESFN has grown in membership from five festivals in 2010 to a height of fourteen; it is currently standing at twelve festivals. Its activities have also diversified, with events conducted under its auspices having involved thousands of actors and creatives; ESFN has reached tens of millions of spectators and readers across the European circuit the Network has established.

Historically, Shakespeare Festival at Globe Neuss, the oldest of the ESFN founding members, was founded in 1991 soon after the fall of the Berlin Wall. The Globe Theatre which houses the event, however, pre-dates the festival and did not start as a permanent structure, nor was it meant exclusively for staging Shakespeare. Envisaged as a mobile construction fit for touring, this Globe began its life in the city of Rheda-Wiedenbrück in 1988 as the venue for the National Garden Festival; to pass safety regulations, the event had to trade mobility for a permanent location in the Neuss district of the Düsseldorf region. As its organisers had no interest in keeping the structure for any future events, it went up for sale and stood unused for two years, during which time several cities expressed interest in it. ${ }^{9}$ The Globe was eventually purchased by the city of Neuss, who turned the twelve-sided steel and wood building into a permanent fixture for Shakespeare work. Since its opening, on 13 September 1991 with a production of The Taming of the Shrew by the Bremer Shakespeare Company, who were instrumental to bringing the structure to the city, Neuss runs as an annual festival that boasts the 'Third Globe' replica theatre. The building houses

6 For more details, see the section on joining at http://esfn.eu/category/join-esfn.

7 The mobility and participation ensured via this affiliation are particularly important for festivals such as Itaka (Serbia), Bitola (Macedonia), and Yerevan (Armenia).

8 One of the first initiatives was 'Shake-in the City', a project which resonated with the 'European Year 2010 - Combating Poverty and Social Exclusion'. For more on this, see http://esfn.eu/projects/shake-inthe-city.

9 Among these cities were Kassel, Frankfurt, Nürnberg, Bochum, and Bremen. 
a 100 square metre stage and 500 seats and offers a month-long summer season of international Shakespeare in its single venue.

The International Shakespeare Festival in Craiova, Romania was founded in 1994. As its founding director Emil Boroghină has often declared, it was inspired by the success and international diversity of the Edinburgh Festival, UK, which the Craiova National Theatre toured with great success right after the country's borders opened after its 1989 Revolution (BOROGHINĂ 2003). The event began as a festival that ran every three years until 2006, and thereafter as a biennial event. Since 2003, it has also run a parallel season in Bucharest featuring some productions from the festival programme and on occasion productions which could not make it to Craiova. ${ }^{10}$ Always scheduled to coincide with Shakespeare's birthday, the festival also programs a rich portfolio of exhibitions, book launches, training, and outreach activities, and has been home to two series of academic seminars: one conducted by the European Theatre Critics' Union and, since 2010, one organised by the European Shakespeare Research Association (ESRA) as its biennial Shakespeare in Performance Seminar series.

As a collaboration between the National Theatre Craiova and the Shakespeare Foundation located in Craiova as its main organisers, the festival continues to boast a fortnightly calendar of international stage productions on several stages ${ }^{11}$ and a plethora of talks, workshops, and open-door conferences. Its rich programme offers ample opportunity to select the International Shakespeare Award, an accolade, and (substantial cash) prize which has primarily gone to directors and only recently to Shakespeare academics whose exceptional work with the festival is primarily acknowledged through doctor honoris causa titles awarded by the University of Craiova, the festival's long-term collaborator and next-door neighbour. ${ }^{12}$ The festival's growing cultural and physical footprint reflects its development and diversification on an upward trajectory: this city festival (one among many in 1990s Romania) has transformed Craiova into a festival city (JOHANSSON 2020) and its biennial programme into events with high cultural impact regionally, nationally, and internationally. ${ }^{13}$

10 The latter are exceptions rather than the rule; they were occasioned by technical constraints (for example, the size and type of venue required to mount the set for the Wooster Group's Hamlet in 2010) or prior commitments which clashed with Craiova festival's calendar of events.

11 Venues have included the National Theatre (main hall, studio, park, and stairs), the Opera House, the Philharmonic, the Students' House, the theatre studio of the Faculty of Agronomy, the Colibri Theatre for Children and Young Adults, open air pop-up stages, the Cult Music Club, and since 2018 the refurbished $19^{\text {th }}$-century landscape garden Parcul Romanescu and its purpose-built outdoor stage.

12 Established by the Festival and UNITER (Theatre Union of Romania) in 2008, the award has gone to Declan Donnellan (2008), Silviu Purcărete (2010), Eimuntas Nekrosius (2012), Sir Stanley Wells (2014), Thomas Ostermeier (2016), and Krzysztof Warlikowski (2018).

13 Acting on these aspirations, the Craiova Shakespeare Festival has worked concertedly with the City Council on the development of heritage, patrimony, and cultural tourism. The bid for the 2021 European Capital of Culture, undoubtedly, galvanised this collaborative energy; however, the much-coveted prize went to Timişoara, Romania. Its programme has attracted increasing international attention, with both productions eager to join its competitive portfolio and wider audiences incentivised by its offer that has been growing in diversity and sheer number from one edition to the next (as the festival schedule covers a fortnight of events). 
Building on the 'Shakespeare Days' which the Theatrum Gedanense Foundation had been running since 1993, the Gdansk Shakespeare Festival opened in 1997 as a summer event intended to coincide with the medieval festivities of the Dominican Fair. ${ }^{14}$ "Always starting on the first Saturday in August' (Limon quoted in VALLS-RUSSELL and ABELLA 2009: 65), the festival progressed from one week of theatre events to a fortnight of eclectic artistic production 'using [...] theatres, the opera house, churches, streets' (63), even windows, e.g., as the TwO Windows Theatre which opened in 2009. With the goal of effecting a larger regional impact, the event has grown to be a tricity festival, with performances and presentations taking place in Gdańsk, Sopot, and Gdynia. Equally, if not more important to the original concept, the festival organisers have also reasserted the city's long-standing Shakespeare connection which in 2014 materialised as the Gdańsk Shakespeare Theatre, a modern space where an early modern fencing school was once located. Designed 'so that it could offer at least three types of space: theatre in the round, that is performing in the yard, with the audience sitting on all four sides, an Elizabethan type of stage and a box stage, a multi-purpose, multispace building' (VALLS-RUSSELL and ABELLA 2009: 62), this venue rounded up the festival director's vision of making available a feast of theatrical spaces in 'a setting that looks ahead to tomorrow while also reclaiming the past' (VALLS-RUSSELL and ABELLA 2009: 66).

Just as versatile in its activities as it is in fundraising, the Gdansk Festival features a rich main programme, a fringe programme entitled ShakespeareOFF, its own theatre competition for the Golden Yorick Prize as well as a daily newsletter which reviews the productions of the previous day and offers short editorials on the post-show interviews and roundtable discussions. In order to put on such a diversity of events over ten days every year, the organisers have worked hard at building their portfolio of sponsors. As festival director Jerzy Limon explained in an interview, the festival is financed by 'the city council, the regional council, and private sponsors', 'occasionally from other institutions' such as 'a Polish-German Foundation', the 'Romanian Cultural Institute', along the 'generous support [that] comes from Brussels' (VALLS-RUSSELL and ABELLA 2009: 62). From its early beginnings, the Gdansk Festival has been 'inseparable from the educational programme' it offers and while it 'does not follow any theatrical vogue' and does not aim to be 'a trendy festival', according to its director Jerzy Limon, this festival manages to set the trend on the ESFN circuit in 'show[ing] a whole range of ways in which Shakespeare is interpreted, shown, used by directors to present themselves and their vision of theatre. We are not purists in the sense that we are attached to the text. Anything goes, provided the aesthetic level is preserved' (Limon quoted in VALLS-RUSSELL and ABELLA 2009: 64). In doing so, the Gdańsk' Shakespeare Festival puts on an annual menu for every taste and budget, with tickets heavily subsidised and a host of free entry events, and as such attracts audiences across demographic spectra, ranging from local and visiting Dominican Fair goers to international Shakespeare aficionados and academics.

14 St. Dominic's Fair is 'one of the biggest commercial open-air events in Europe. It was established in 1260 by Pope Alexander IV, and since then has been annually organised in the streets of Gdańsk - with the short period of a break during and after the Second World War' (EXPLORE GDANSK 2020). 
The first child of the third millennium, the Shakespeare Festival of Catalonia was born in 2003 in Santa Susanna, a small town in the Maresme region of Spain. In a move meant to capitalise on its success, it was relocated to the capital of the region Mataró between 2008 and 2010. For its $10^{\text {th }}$ anniversary in 2013 it was moved to Barcelona in a bid to attract wider funding and involvement from other institutions such as the University of Barcelona, the Centre for Contemporary Culture and the Film Archive. Unfortunately, the initiative was not met with the same enthusiasm and the festival became the first casualty of the Network: it was suspended after its 2015 edition.

Founded only a year later, the Yerevan International Shakespeare Theater Festival in Armenia (2004) was the joint venture of Armenian director Hakob Ghazanchyan and Polish Shakespeare scholar Andrzej Żurowski. Its festival signature was staging monodramas only; having done this with relative success for three years, the festival eventually opened its doors to other artistic forms. This development aimed at enhancing its programme for the wider public as well as at diversifying opportunities by offering masterclasses for professionals, students, and anyone else interested in theatre, alongside open talks and opportunities to meet the artists - a natural direction of growth given the festival's grounding in the theatre and having a director at its helm.

Launched in 2005 in Hungary, the Gyula Shakespeare Festival is a site-specific event that is held in the only surviving late medieval fortress ${ }^{15}$ in Central Europe. The Gyula Festival was the brainchild of József Gedeon, a local prodigy and a man of many talents. While the Shakespeare focus was entirely his, the idea of turning the Gyula Castle into a theatre was not new; theatre director István Miszlay, the mastermind behind the foundation of the Gyula Castle Theatre in 1964, was inspired by the Dubrovnik Summer Festival, which had been running since 1950. The geographical position of the venue (that is, its safe distance from the censoring hand of the capital city and its proximity to the borders of three countries: Hungary, Romania, and Serbia) lent the festival a natural multicultural flavour that went hand in hand with its community ethos (SHEVTSOVA 2011). Director of the venue since 1995, Gedeon envisaged the Shakespeare Festival as one week of the six-week-long all-arts festivalling that takes over not only the castle but the entire city every year during mid-summer. Performances by professionals and amateurs, including high and popular music and dance, make Gyula - the castle, town, and even the lakeside stage - a sought-after destination for Shakespeare and jazz.

A year of rich Shakespeare celebrations, 2016 was also a turning point for the Gyula Shakespeare Festival. The death of managing director Gedeon marked the end of an era, an end that coincided, one cannot help but notice, with a political turn to the right, not only in Hungary, but as part of the general rise in nationalism in Europe and overseas. ${ }^{16}$

15 Gyula fortress was built in the fifteenth century and reshaped in the sixteenth century when it was repurposed as a fortification, part of the defence line against the Turks, who laid siege to it in 1566 and occupied the fortress (PIKLI 2020b).

16 This is true of countries on both sides of the former Berlin Wall divide, as the list includes Austria, Belgium, Denmark, Finland, France, as well as Hungary, Poland, and the UK (BBC 2019). In Belgium, in 2019 the far-right won 'in the more prosperous Dutch-speaking Flanders region, while voters in French-speaking Wallonia gave leftist parties a clear win. This results in an ever more polarised parliament at federal level, where each region has a pre-determined number of seats. With the exception of the Greens, this means 
In the case of this festival, this meant not only the (re)centralisation of theatre funding, which led to a shorter season, but also the scrutiny of its focus on Shakespeare, which led to the identification of the event itself in 2018 by the new director Tibor Elek as the 'foreign bard festival'; while he did not entirely abolish the festival's international format established by his precursor, he 'shortened it a bit and invited performances somewhat closer to mass taste' (UNGARN-TV 2018). For 2020, Shakespeare at Gyula aimed at an exclusive Hungarian flavour; early advertising (in January) anticipated that the Gyula Festival season would start with the usual Sándor Márai days ${ }^{17}$, followed by the Shakespeare Festival for a week of productions in Hungarian only, and that at the beginning of August, the Transylvanian Week Theatre Festival would be held for the third time (GYULATELEVIZIO.HU 2020).

Joining the large Czech-Slovak project entitled The Summer Shakespeare Festivities that takes place in four different castles in the Czech Republic and Slovakia, the Ostrava Festival, the only event in the former Czechoslovakia to join ESFN, was founded in 2008. The array of international Shakespeare productions treads the boards of a purposebuilt open-air stage, making this another Shakespeare summer delight where spectating is always embedded in heritage site-specificity. According to Jana Wild (2020), the festival 'has given Czech and Slovak actors the opportunity to join in the same production, each speaking their own language (Czech or Slovak). This also meant that the new translators had to agree on each other's texts: for example, Jiří Josek delivered his new Czech translation and the Slovak translator Lubomír Feldek added his Slovak texts to the corresponding Slovak actor(s)' (WILD 2020). She argues that such mutual linguistic co-operation was the order of the day, although 'neither with actors nor with translators - during the era of Czechoslovakia (where there were two languages, too). However, the practice of multilingual Shakespeare performances was widespread in Europe in the nineteenth century' (WILD 2020).

Although backed by a tradition that goes back to 1816, the annual Shakespeare Festival at Hamlet's Castle is as recent an addition to the festival circuit as is the Ostrava Festival. First hosted in 2008 by HamletScenen, a resident subsidised theatre in Kronborg since the same year, this festival remains a much desired and attractive theatre location for productions of the Shakespeare play that is site-specific to this location (Elsinore): Hamlet. A much-envied accolade in any actor's career, Helsingør has seen many Princes - from Laurence Olivier and John Gielgud, Michael Caine and Richard Burton, to Kenneth Branagh and Jude Law - and remains the 'custodian of the oldest continuous Shakespeare tradition in the world' (BBC 2021).

the country's linguistic divide is now also clearly doubled by a political divide' (BRZOZOWSKI 2019). In Poland, the right-wing populist party won with the slimmest margin since 1989: the president, 'Mr Duda is a social conservative allied with the government led by the nationalist Law and Justice (PiS) party, while Mr Trzaskowski [his opponent] is the socially liberal mayor of Warsaw' (BBC 2020).

17 The festival hosts several days of events dedicated to Sándor Márai, a prolific Hungarian interwar writer who escaped the Communists' persecution in 1948 to live as an émigré in Europe and eventually settle in San Diego, where he committed suicide in 1989. Publishing over 60 volumes during his lifetime, Márai was a 'poet, journalist, dramatist, translator, novelist and essayist, [who] worked in just about every literary form, but for Hungarians it's probably the diaries that excite the greatest admiration' (FISCHER 2007). 
The London Globe was a halfway house between the American concept of a festival $^{18}$ and the Network's when it organised alongside the 2012 Olympics its Globeto-Globe seven-week season of the World Shakespeare Festival and its world tour of Hamlet between April 2014 and April 2016. As Erin Sullivan recalls, 'from April to June, 37 of Shakespeare's plays and a dramatic rendering of one of his narrative poems performed in as many languages by as many theatre companies' (SULLIVAN 2013: 7) treaded the boards of the London Globe with performances invited or commissioned especially for the occasion. As its self-presentation on the ESFN website puts it, 'with a regular annual international touring programme, performances from Shakespeare's Globe can be seen worldwide every year, while the celebration that is the Globe-to-Globe invites a number of world-class productions, in a variety of languages, to play alongside its own work' (ESFN 2021). Unlike the other ESFN festivals it has joined, the London Globe represents a repertory theatre (and as such is akin to the American concept and practice of Shakespeare festivals), some of whose productions travel the world increasingly more as streamed - live or encore - versions and less in flesh and blood. Nevertheless, it was its 2012 Globe-to-Globe that gave birth to two other festivals, both of which joined ESFN in 2014: the Bitola Shakespeare Festival in Macedonia and the Itaka Shakespeare Festival in Serbia.

Like Globe-to-Globe, the Bitola Shakespeare Festival proceeds from the vision of a single institution: the Bitola Theatre, the National Theatre of Macedonia. Like other fellow festivals in ESFN, it takes place on several stage spaces within the theatre and outdoors, and seeks to capitalise on local attractions such as the Ancient Theatre of Heraclea which is only two kilometres away from Bitola. Much like the founding festivals of the Network did in their early stages of existence, Bitola divides its attention between bringing international Shakespeare productions to Macedonia and effecting artistic exchanges between Macedonian theatres.

Shakespeare's $450^{\text {th }}$ birthday anniversary year of 2014 saw the birth of another festival: Théâtre National de Nice initiated The Shake Nice! Festival, the first (and to my knowledge, the only) Shakespeare festival in France. Founded by director Irina Brook, the Festival hosts a schedule of international Shakespeare productions as well as a programme of Shakespeare Freestyle for teenagers, thus adding educational focus to its aim of being an accessible festival helping social integration by 'weaving together not only the various components of an enlarged audience in the playhouse but also, beyond its walls, the different geographical areas of Nice, a multifaceted city with sharp social, cultural and political contrasts' (MARCH and VALLS-RUSSELL 2016: 158). The strong community and educational ethos of this festival have been welcomed with open arms in Nice, as well as the broader Network, because it brought innovative ways of effecting not only cultural, but social and economic change.

18 For first-hand experience and informed opinion, I have invited Paul Prescott to sum up the main characteristics of the American Shakespeare festivals. Having tracked Shakespeare festivals in the USA in 2014, through the project: Shakespeare on the Road, Prescott concludes that they are seasonal producing companies (vested in their communities as they work with local actors and primarily for local audiences). They rarely host visiting productions, and it is even more rare for these productions to be non-Anglophone (PRESCOTT 2021). 
The festival director toured with success events in the ESFN circuit, and her work began to impact on the respective festival's engagement with their locale and community. In Craiova, for example, Irina Brook's Tempête!, initially scheduled at the Colibri Theatre for Children and Young Adults, relocated at the company's request to the outdoor stage of the Nicolae Romanescu Park for two performances. As a result, the performances

took place at night, in an open-air amphitheatre with a capacity of 800. Director Irina Brook was eager to develop a relationship of proximity and complicity with a vast audience, on the model of Shakespearean popular theatre, and the raised proscenium stage of the Colibri might have been an obstacle. This change fitted the intention of the Festival's newly appointed director, Ilarian Ştefănescu, to tighten the links with the city by bringing the theatre out of the walls of the institutional buildings as much as possible. (MARCH et al. 2019: 119)

The impromptu change turned into an opportunity for the festival to expand its city footprint and audience outreach as the 'recently restored [...] historic park had never been used as a venue for the Festival before the 2018 edition' (MARCH et al. 2019: 119), save for one performance a few nights before. Frequented by 'families [of all ages], the Romanescu Park provided an intergenerational audience, not all familiar with the codes and conventions of the theatre' (MARCH et al. 2019: 119). The festival's commitment to and practice of bringing local communities together will be sorely missed on the Shakestivalling scene as much as at home; while Shake Nice! has been short-lived (it had ceased to exist by the end of 2019), one can only hope that the seeds it sowed have fallen on fertile soil.

Also a 2014 baby, the Itaka Shakespeare Festival in Serbia is a destination festival that takes place in June in the beautiful setting of Villa Stankovic on the Danube bank in Čortanovci. Dubbed one of the most scenic residencies in the country, this venue was built in the 1880 s on the local Roman site called the 'Golden Hill' in the style of Serbian medieval castles and modelled on castles in Lombardy. It remained closed to the public (even when nationalised) and it only opened to visitors for the first time on the occasion of the festival (SHAKESPEARE FESTIVAL 2018). Besides the main programme of open-air performances, the festival also schedules a range of multimedia and educational activities, including a young directors' competition in a programme that confirms its important role in curating Shakespeare and other stage practices in Serbia.

The latest addition to the Network is the York International Shakespeare Festival. Inaugurated in 2015, this festival started life as a major new cultural venture for the city and the north of England as a whole. Developed as a three-way partnership between the York Theatre Royal, the University of York, and Philip Parr's Parrabbola (one of the founding members of the Network linked to Bath at the time), this festival and the programme it has been running focus more on 'Shakespeare in the North' - as opposed to the heavily subsidised London and Stratford-upon-Avon Shakespeare - than on international cultural exchange. 
This biennial festival works to put York on the UK Shakespeare map by capitalising on the city's reputation and long history of heritage tourist destination and less on a Shakespeare connection: it casts York, 'the powerhouse of the North of England in Shakespearean times' as 'the ideal location to reflect on the variety and complexity of Shakespeare as Europe's playwright' (ESFN 2021) and turns York into 'the city of Shakespeare' over ten days of diverse events, ranging from live performances indoors and in the streets, to multimedia exhibitions, workshops, outreach activities for different age groups, and an international academic conference. With its pop-up Rose Theatre no longer a unique feature in the UK (as another one popped up at Blenheim Palace in 2019), the York International Shakespeare Festival is likely to change both tack and flavour.

\section{Taking stock, looking ahead}

The first part of the present article has mapped out the rich Shakestivalling across Europe along with ESFN as a structure, and in doing so acknowledged 'the unity in diversity' within the Network, which currently boasts eleven festivals plus the Globe-toGlobe. In between the lines, it has also seen the Network as a form of agency which is conveyed discretely or collaboratively by its members. My account posits that, though individually negotiated, each festival's respective 'European connection' remains intrinsically linked to the geo-political re-membering of Europe as well as the visibility and increased economic prowess afforded through such affiliation. The chronology alone confirms it, with the oldest festivals born immediately after the fall of the Berlin Wall (Neuss, Craiova, Gdańsk) and the later joinings symptomatic of the more recent European Union expansion waves. More importantly, though, the Network's geographic span and one decade of activity confirm Shakespeare's dynamic role in intercultural celebration, mobility, and mediation, all newly-earned freedoms at key re-mappings of Europe: immediately after 1989, after the EU expansion in 2004, and at recent Shakespeare anniversaries - of his birth in 2014 and his death in 2016. Finally, it legitimises Shakestivalling in Europe as a phenomenon that has been gathering momentum, energy, and agency.

What follows is my attempt to articulate some of the potential directions the future conceptualisation and study of this complex and fluid phenomenon, as well as its cultural, social and political impact, would need to take into account in the context of both Europe's transformations and of Shakespeare Tourism, a field of Shakespeare studies currently in full developmental swing. ${ }^{19}$

Firstly, as my retrospective look at the ESFN's first decade of activity suggests, a study of Shakestivalling and, implicitly, of ESFN, would do well to examine the role they con-

19 In this sense, it is worth noting that the two recent publications Shakespeare and Tourism: Place, Memory, Participation edited by Marta Minier and Maddalena Pennacchia (2019), and The Cambridge Companion to International Theatre Festivals (2020) discuss Shakespeare and European festivals, but not European Shakespeare Festivals as a distinct phenomenon. 
tinue to play in regional socio-cultural exchanges - not least given the tensions between the new and neo-European movements that threaten Europe's and the EU's 'unity', with ripple effects for the rest of the world. Back in 2014, the proposal in Brussels of a group of scholars to make Shakespeare the first Poet Laureate of Europe became all the more poignant as it was happening at the time when Ukraine was being invaded by Russia precisely on the grounds that the former was leaning towards 'Europe'. There were even richer promises of revelry in celebration of Shakespeare's long-lasting work and heritage (rather than the quatercentenary of his death) in 2016. In terms of Shakestivalling, this was a true 'embarrassment of riches', with regular events outdoing themselves and new initiatives (joint celebrations, such as the Shakespeare-Cervantes, or the 400 Shakespeare 400 Merchant of Venice) scheduled around the globe. Just halfway through, this rich Shakestivalling year was hijacked by political crises - European and international. The UK's vote to leave the EU and the election of Donald Trump as President of the USA turned the 'auspicious' into 'a dropping eye' and the 'mirth in funeral' (Hamlet 1.2.214-215), and overturned the world as we knew it, a change reflected in how Shakespeare was staged soon after. Several productions of Julius Caesar opened on both sides of the Atlantic: the one staged by the Public Theater in New York's Central Park was disrupted by protesters and boycotted by US firms for drawing overt parallels between Caesar's Rome and present-day America (GILBERT 2017). An entire Roman season staged by the Royal Shakespeare Company in Stratford-upon-Avon (2016-2017) engaged with the political tensions unleashed by the Brexit divide (CINPOES 2020). That it became neigh on impossible to 'weigh delight and dole' in 'equal scale' (Hamlet 1.2.216) soon became visible, with more nationalist voices threatening dissent and, as a consequence, shake and spear through the European community. While 'nationalism has always been a feature across Europe's political spectrum', a 2019 country-by-country survey by the BBC shows that 'there has been a recent boom in voter support for right-wing and populist parties' in the recent years (BBC 2019). Once again, it was Julius Caesar that showcased the dangers of populism in the UK, USA, and elsewhere, in a stage production mounted by the Bridge Theatre, London in the 2018-2019 season, whose programme commissioned Matthew D'Ancona's piece 'A Political Text for Our Times: Post Truth, Populism and Public Emotion in Julius Caesar' (D'ANCONA 2018).

Secondly, notwithstanding the positive impact Shakestivalling and ESFN has had on staged Shakespeare - documented and acknowledged primarily by individual festivals it is worth examining the impact festivals have on the production and circulation of staged Shakespeare. On the one hand, it is evident that as older member festivals have moved and more recent entrants are moving past the stage of seeing the Network as a structure which facilitates artistic national catching up with international Shakespeare and a dose of mutual regional exchange, in more recent years the Network has been instrumental in effecting change, with individual festivals thus gaining agential traction in areas beyond the artistic and the cultural, and into the civic, educational, and socioeconomic domains..$^{20}$

20 This has been the case of a number of Shakespeare festivals, two obvious examples being Gdańsk's and Craiova's, the festivals I have followed closely since 2006. The recent awards they have received confirm that 
On the other hand, it is also worth examining whether or not individual artists (primarily directors), companies and/or theatres consider, when planning a Shakespeare production (as opposed to any other in their repertoire), the European market and audiences of festivals, and if so, how these 'export' productions compete with local priorities (of the artist, the company, the theatre or national repertoire). With runs longer by virtue of productions staying on the ESFN circuit, the rhythm of theatre seasons and annual plans is necessarily affected. The effects can sometimes be positive, sometimes less so, if we think, for example, of the Lithuanian Hamlet directed by Eimuntas Nekrosius which was politically and aesthetically fresh in 1997 but had lost some of its currency by the time it reached Craiova in 2010 and London as late as 2012. Or to provide another example, the international collaborative endeavours which, despite their best intentions and attractiveness (at the level of raising the interest of artists, spectators, and sponsors), may become time and resource draining, and by contrast, short-lived (if not locally unsustainable) productions.

Additionally, Shakespeare festivals in Europe affect curating Shakespeare both at the individual level and at that of the Network, not least due to facilitating mutual exchanges as well as competitiveness and competition in an unregulated neo-liberal market $^{21}$ (HARVIE 2020). However, one cannot but wonder were it not for the existence of any of the twelve Shakespeare festivals, how many indigenous Shakespeare productions and of which plays would be staged otherwise - whether at that particular theatre, in that language and country, or at other theatres elsewhere? Do such festivals reinforce the 'Shakespearean hegemony' - albeit a later starter phenomenon for many Central and Eastern European countries, where Shakespeare became a national icon at the beginning of the nineteenth century - as the Globe-to-Globe did for Britain 'even if' it 'confront[ed] Londoners with the unpleasant realization that the most interesting productions of the bard's plays come dressed in foreign costumes [...] it's still the empire of culture that colonized those distant lands, mining their traditions to spice up the British imagination' (Lobanov-Rostovsky quoted in SULLIVAN 2013: 8)? What kind of experience does a Shakespeare play afford that a non-Shakespeare play may not? And, ultimately, what is the relevance of Shakespeare today?

Thirdly, as my survey has inferred, Shakestivalling has played an important part in recasting hierarchies: written text versus performance, the Anglo-centred dichotomy of English-speaking versus 'foreign', repositioning all non-local Shakespeare as 'foreign',

their activity has impacted beyond their respective city and region not only culturally, but civically and socially. The Gdańsk Shakespeare Festival received the Europe for Festivals - Festivals for Europe (EFFE) Award in 2017 (ESFN 2021). The Craiova Shakespeare Festival received the UNITER Excellence Award for the 2006 edition and the International Association of Theatre Critics' Award in 2016, and Craiova Festival's director Emil Boroghină received a number of accolades: the Man of the $21^{\text {th }}$ Century distinction awarded by the International Biographical Centre Cambridge (2001), the UNITER British Council Award for Best Theatre Manager in Romania (in 1997 and 2015), the British Council Prize for Lifetime Achievement in Promoting British-Romanian Cultural Relations (2011), the Constantin Brincoveanu Prize honouring exceptional Romanian cultural figures (2019) (BOROGHINĂ 2020).

21 Harvie's (2020) discussion of the implications of the neo-liberal model used by the Edinburgh Fringe Festival is pertinent especially to the 'off' (fringe) part of their programmes that some European Shakespeare Festivals offer. 
including English, indoor versus outdoor, physical versus intermedial performance, high versus popular culture. As a practice, therefore, it offers productive exploration of some much-debated concepts - authenticity, appropriation, community - as well as of more recent ones, such as reversed 'othering' and the Shakespeare tourist's gaze, as by its very nature, Shakestivalling invests growing communities of 'willing strangers' (KENNEDY 1998), that is, its local and global audiences, in the roles of 'prodsumers' and 'produsers' (MINIER and PENNACCHIA 2019: 15). While occurring in the context of analogue experienced festivals, this blurring of the boundaries between producers, consumers, and end-users is emphasised further in the digi-sphere where some, if not all creatives (actors, tech-teams, spectators), are 'virtually there'.

As with most developments - some of which have been discussed in this article, others which require further research - there are gains and losses. Besides democratising theatre-going, it will be worth exploring how the experience economy that Shakestivalling is part of drives local/regional regeneration and development, as well as how it might also effect displacement - cultural and otherwise, as the pace of gentrification is accelerated by the annual/biennial programmes of events. Bemoaned by the avid Shakespeare festival tourist, the tilting of the festivalling balance of sight and site in favour of the former by going digital might also incentivise a more moral form of tourism, or at least one with a smaller carbon footprint.

Finally, at the start of this project it appeared urgent to explore whether the live experience of the Festival Shakespeare would be threatened by the streaming of live Shakespeare performances - primarily from London and Stratford - globally. I was also musing over whether, conversely, festivals would - eventually - consider making streaming one of their distributors, that is, finding a truly global audience for their vision of global theatre. Some festivals rejected such a possibility outright (Limon quoted in VALLS-RUSSELL and ABELLA 2009) while others resorted to it as the last, and one off, option when a company could not get to a festival because of a natural disaster as was the case of the Ryutopia, whose Japanese Hamlet was streamed as an encore in Craiova in 2010 when the company was stranded in Paris because of the eruption of the Eyjafjallajökull volcano that played havoc with air travel - or funding dire straits. In the wake of the Covid-19 pandemic which has seen the lockdown of country after country and, with it, of theatres around the world, streaming theatre performances has become a much more urgent matter and a reality. With live theatrical activity and mobility - in the physical sense and as understood so far - frozen, for the foreseeable future, Shakestivalling has also been affected.

In the absence of its two intrinsic and defining features: namely live-ness and mobility, festivals, too, are metamorphosing. The first such other-ness was Craiova's, whose two-week programme, due to start on site on 23 April 2020, 'melted into air, into thin air' in March as governments attempted to contain the spread and impact of the pandemic. However, it emerged - albeit in a different guise - on Shakespeare's birthday anniversary as the 'Shakespeare Festival - home edition'. The first Shakespeare festival entirely online, Craiova 2020 scored several other firsts: its week-long programme comprised of non-simultaneous events (an unachievable dream previously) that alternated 
between scheduled live interventions and posted messages from around the globe as well as encores of handpicked productions streamed on its Facebook platform, a productive exercise in digging deep into its rich and unique archive, and in testing the potential of Shakestivalling. ${ }^{22}$ Across the border, two months later, Gyula managed to offer 'two days and three performances of Shakespeare' live to audiences keen to return to analogue participatory experiences (ALMÁSI 2020). The ambitious initial plans were reduced to "a strangely divided and very short "festival". First, a weekend in July was dedicated to three Shakespearean performances in Hungarian productions The Comedy of Errors by a young and talented ensemble' directed by Dániel Dicső, and 'two musical adaptations, one of the Sonnets, the other based on Othello - followed by a talk with scholars and artists. The last Saturday in August became the final event in 2020's unusual Shakespeare Festival, with Hamlet in a Romanian-Hungarian production' (PIKLI 2020b). ${ }^{23}$ As Natália Pikli (2020b) put it in her review of The Comedy of Errors, this first live Shakespeare in the pandemic was a 'turbocharged', 'tantalising' experience that appealed to a diverse audience. Besides Shakespeare aficionados and the Festival's regulars, there were 'invited social and health workers, along with children, teenagers [...] who met Shakespeare for the first time, all of whom 'enjoyed the thought-provoking and endlessly entertaining farce taking place on the Lake Stage' (PIKLI 2020a). Ostrava eventually got the green light to run, a decision 'conditioned by a number of safety measures, such as mandatory masks, disinfection, and the like' and a streamlined programme of five productions, none of them new (PAS DE THEATRE S.R.O. 2020). While some festivals braved the pandemic climate and regulations to hold their regular festivities, others have opted to delay, and very likely scale down, their programmes - Itaka initially until August and then mid-September, and Gdańsk until November 2020.

Between Craiova's and Gdańsk's respective 2020 editions, Shakestivalling has wisened up to the enablements the online realm opened up as well as to its challenges. On the plus side, both festival makers and audiences have relished in not having to negotiate performance spaces and to deal with simultaneous productions. The fact that there were plenty of seats in these virtual theatre venues, all free of charge, made up

22 Despite the short notice move to a 'from home' edition, the Craiova Festival attracted around 80,000 online participants across its programme of events. While the data is yet to be analysed (how many individuals as opposed to how many log-ins, site of access, age/gender/occupation diversity, choice of production, etc.), the appeal of this format is undoubtedly related to the timing of the Festival - early in the theatre lock-down, when little if anything was available for theatre-savvy audiences.

23 For details on Gyula 2020, I am indebted to Natália Pikli, who explains that, over the past few years, director Dániel Dicső has been cooperating with the House of Culture/Community Centre (Múvelődési Ház) in Óbuda, a district of Budapest, to stage an open-air show in the summer. This collaboration includes an adaptation of A Midsummer Night's Dream (2015), productions of Much Ado About Nothing (2016), of Ferenc Molnár's Carousel (2017), Romeo and Juliet (2018), and The Comedy of Errors (2019) - the last being invited by the Gyula Shakespeare Festival organisers to perform in their shortened edition in 2020. The talk was Natália Pikli's initiative, who in her role as the current President of the Hungarian Shakespeare Committee proposed the post-show talk to the festival organisers; the event, which took place late into the night after the performance of The Comedy or Errors, involved the director and fellow academics Zsolt Almási and Sándor Fazekas (PIKLI 2020b). 
for the comparatively fewer shows on offer. Conversely, copyright and funding matters negatively affected the variety of offerings of the overall programmes. By the time the Gdańsk Festival went fully online in November 2020, there was a general increase in online platform diversity as well as in the competition for the time and attention of potential audiences. As the audiences grew more international, the festival programmes grew less so. For example, while Gdańsk stayed true to its ten days of revels model, it required registration (on the VOD platform) for its programme and included a maximum of two productions a day, most of which were between 30 and 90 minutes long (FESTIWAL SZEKSPIROWSKI 2020). ${ }^{24}$ The offerings remained diverse in terms of Shakespeare play choice and staging, but primarily indigenous (as was the case of the Gyula Festival and the Craiova Festival). Fifteen Polish productions from across the country were joined by one Italian production along with two events that were part of the broader international project Shake the Walls. The two events: Shake Fear/Break Walls presented by Parrabbola, UK, and SUSS by RaTaTam, Iceland, showcased the project's goal, to give artistic shape to various kinds of real and metaphorical walls that divide people, individual, social and racial groups, nations and countries', fulfilled its diversity mission to 'create co-operation between different groups of Europeans, including diverse social groups, countries, age groups and professional circles', and continuing to 'foster intercultural dialogue' (SHAKING THE WALLS 2021). Its mission statement was: 'Shaking the Walls - To Change the World' (SHAKING THE WALLS 2021), and the five-way partnering of the project - which brought together founding members, recent joiners and potential future members (SHAKING THE WALLS 2021) ${ }^{25}$ - echoed both the fall of the Berlin Wall and the early days of Shakestivalling that gave birth to ESFN, which changed Europe and European Shakespeare.

Back in 1994, the editors of Shakespeare and the New Europe remembered the 1992 conference that generated the first collaborative effort on this very topic as an event which 'spent time unpacking the ways in which Shakespearean texts [...] have always served as a register and touchstone for social and political change', warned that 'dogmatic Marxism could be replaced by dogmatic liberalism' and concluded that 'Shakespeare never offered reflections of contemporary realities but always reflections upon them' (HATTAWAY et al. 2015: 18-19).

While a fit celebration of the ESFN's $10^{\text {th }}$ anniversary, the project Shake the Walls at the Gdansk Festival in 2020 also served as a reminder of how true the above words still ring twenty-five years on. It is precisely a venture such as Shake the Walls that invites us to take heart from the topicality, the resilience and the versatility of Shakespeare collaboration, and renews hope in the work Shakestivalling continues to do. As our new life unfolds in a world which continues to struggle with the pandemic and with theatres negotiating waves of dark lockdowns, Shakestivalling in Europe is clearly set to continue - in what creative guises, it remains to be seen ...

24 Out of the 18 productions, only three reached 120 minutes in length and one was 170 minutes long.

25 The Gdańsk Shakespeare Theatre led the project in partnership with Cooltour - Kulturní centrum Cooltour Ostrava z.ú (Czech Republic), RaTaTam - Reykjavik Art Group (Iceland), Parrabbola - community collective (London, UK), and An Grianán Theatre (Letterkenny, Ireland). 


\section{Bibliography}

ALMÁSI, Zsolt. 2020. Shakespeare Járvány Idején. Gyulai Shakespeare Fesztivál 2020 [Shakespeare during Pandemic: Gyula Shakespeare Festival 2020]. PRAE (16. 07. 2020). [accessed 28.08.2020]. Available online at https://www.prae.hu/article/11665-shakespeare-jarvany-idejen/.

BBC. 2019. Europe and right-wing nationalism: A country-by-country guide. BBC News (13. 11. 2019). [accessed 28.09.2020]. Available online at https://www.bbc.co.uk/news/world-europe-36130006.

BBC. 2020. Poland's Duda Narrowly Beats Trzaskowski in Presidential Vote. BBC News (13. 07. 2020). [accessed 28.09.2020]. Available online at https://www.bbc.co.uk/news/world-europe-53385021.

BBC. 2021. Elsinore - A Castle Fit for a Prince. Shakespeare 2016 Lives BBC website. 2021. [accessed 18.01.2021]. Available online at https://www.bbc.co.uk/programmes/articles/5Dq19R rP11JVGYKm8PLh0z1/elsinore-a-castle-fit-for-a-prince.

BOROGHINĂ, Emil. 2003. Personal interview with Emil Boroghină, Director of the International Shakespeare Festival in Craiova, Romania. Interviewed by Nicoleta Cinpoeş. (13. 08. 2003).

BOROGHINĂ, Emil. 2020. Personal interview with Emil Boroghină, Honorary Director of the International Shakespeare Festival in Craiova, Romania. Interviewed by Nicoleta Cinpoeş. (29. 01. 2020).

BRZOZOWSKI, Alexandra. 2019. Belgium's 'Black Sunday' Sees Far-right Surge, Threatens New Government Crisis. Euroactive.com (27. 05. 2019). [accessed 28.09.2020]. Available online at https://www.euractiv.com/section/eu-elections-2019/news/belgian-black-sunday-sees-farright-surge-threatening-new-government-crisis/.

CINPOEŞ, Nicoleta and Janice VALLS-RUSSELL. 2019a. Craiova International Shakespeare Festival, 23 April-6 May 2018. Cahiers Élisabéthains 100 (2019): 1: 75-79.

CINPOESS, Nicoleta and Janice VALLS-RUSSELL. 2019b. Prologue: Viewing and Reviewing 'Planet Shakespeare' (Craiova, 23 April-6 May 2018). Cahiers Élisabéthains 100 (2019): 1: 51-55.

CINPOES,, Nicoleta, Florence MARCH and Paul PRESCOTT (eds.). 2022. Shakespeare on the European Festival Stages. London: Bloomsbury, 2022, forthcoming.

CINPOEŞ, Nicoleta. 2020. 'So our virtues / Lie in the interpretation of the time': The Royal Shakespeare Company Rome Season (2017). In Marta Gibińska et al. (eds.). This Treasure of Theatre. Gdańsk: Słowo/Obraz Terytoria, 2020: 88-102

D'ANCONA, Matthew. 2018. A Political Text for Our Times: Post Truth, Populism and Public Emotion in Julius Caesar. Bridge Theatre (20.01.2018). [accessed 28.01.2021] Available online at https://bridgetheatre.co.uk/a-political-text-for-our-times-post-truth-populism-and-publicemotion-in-julius-caesar/.

ENGLE, Ron, Felicia HARDINSON LONDRÉ and Daniel J. WATERMEIER (eds.). 1995. Shakespeare Companies and Festivals: An International Guide. Westport and London: Greenwood Press, 1995.

ESFN. 2010. The Articles of Association: The Foundation of the European Shakespeare Festivals Network, 2010: 1-11. Courtesy of the ESFN secretary.

ESFN. 2021. ESFN: European Shakespeare Festivals Network. [accessed 18.01.2021]. Available online at http://esfn.eu. 
EXPLORE GDANSK. 2020. [accessed 24.01.2021]. Available online at https://exploregdansk. info/events/st-dominics-fair-in-gdansk/.

FESTIWAL SZEKSPIROWSKI. 2020. [accessed 16.12.2020]. Available online at http://festiwalszekspirowski.pl/en.

FISCHER, Tibor. 2007. Hungarian Graffiti. New York Times (28. 04. 2007). [accessed 24.01.2021] Available online at https://www.nytimes.com/2007/04/29/books/review/Fischer.t.html.

GILBERT, Sophie. 2017. The Misplaced Outrage Over a Trumpian Julius Caesar. The Atlantic (12. 06. 2017). [accessed 28.01.2021] Available online at https://www.theatlantic.com/entertainment/archive/2017/06/the-misplaced-outrage-over-a-trumpian-julius-caesar/530037/.

GYULATELEVIZIO.HU. 2020. Csak magyar nyelvű előadásokat mutatnak be a Shakespeare Fesztiválon [Only Performances in Hungarian will be Presented at the Shakespeare Festival], (22. 01. 2020). [accessed 24.01.2021] Available online at https://www.gyulatelevizio. hu/2020/01/22/csak-magyar-nyelvu-eloadasokat-mutatnak-be-a-shakespeare-fesztivalon/.

HARVIE, Jen. 2020. International Theatre Festivals in the UK: The Edinburgh Festival Fringe as a Model Neo-liberal Market. In Ric Knowles (ed.). The Cambridge Companion to International Theatre Festivals. Cambridge: Cambridge University Press, 2020: 101-117.

HATTAWAY, Michael, Boika SOKOLOVA and Derek ROPER (eds.). 2015. Shakespeare in the New Europe. London: Bloomsbury, 2015.

JOHANSSON, Marjana. 2020. City Festivals and Festival Cities. In Ric Knowles (ed.). The Cambridge Companion to International Theatre Festivals. Cambridge: Cambridge University Press, 2020: 54-69.

KENNEDY, Dennis. 1998. Shakespeare and Cultural Tourism. Theatre Journal 50 (May 1998): 2: $175-188$,

KNOWLES, Ric (ed.). 2020. The Cambridge Companion to International Theatre Festivals. Cambridge: Cambridge University Press, 2020.

MARCH, Florence and Janice VALLS-RUSSELL. 2016. Shaking up Shakespeare in Europe - Two New Festivals. Cahiers Élisabéthains 90 (2016): 1: 155-170.

MARCH, Florence et al. 2019. Review: Tempéte! Cahiers Élizabéthains 100 (2019): 1: 119-120.

MINIER, Márta and Maddalena PENNACCHIA. 2019. Place, Memory, Participation: Shakespeare and Tourism in Focus. In Márta Minier and Maddalena Pennacchia (eds.). Shakespeare and Tourism: Place, Memory, Participation. Napoli: Edizioni Scientifiche Italiane, 2019: 9-24.

ORMSBY, Robert. 2017. Shakespearean Tourism - From National Heritage to Global Attraction.

In Jill L. Levenson and Robert Ormsby (eds.). The Shakespearean World. London: Routledge, 2017: 431-442.

PAS DE THEATRE S.R.O. 2020. Shakespearova - Ostrava Shakespeare Festival. [accessed 31.08.2020]. Available online at https://www.shakespearova.cz/cz/program-2020-letni-shakespearovske-slavnosti-ostrava/4/.

PIKLI, Natália. 2020a. Érzelmeink labirintusában: A Tévedések vígjátéka a gyulai Tószínpadon [In the Maze of our Emotions: The Comedy of Errors on the Lake Stage of Gyula]. PRAE (16. 07. 2020). [accessed 13.09.2020]. Available online at https://www.prae.hu/article/11666-erzelmeink-labirintusaban/.

PIKLI, Natália. 2020b. Personal correspondence with the author (12. 09. 2020).

PRESCOTT, Paul. 2021. Personal correspondence with the author (26. 01. 2021). 
SHAKESPEARE FESTIVAL. 2018. Villa Stankovic. [accessed 31.09.2020]. Available online at http://sekspirfestival.org/villa-stankovic/?lang=en.

SHAKESPEARE, William. 2016. Hamlet. Ed. by Ann Thompson and Gary Taylor. London: Bloomsbury, 2016.

SHAKING THE WALLS. 2021. [accessed 16.12.2020]. Available online at http://shakingthewalls. $\mathrm{eu} /$.

SHEVTSOVA, Maria. 2011. The Gyula Shakespeare Festival 2011. New Theatre Quarterly 27 (2011): 4: 386-394.

SHEVTSOVA, Maria. 2012. Reasons for Joy and Reflection: Engaging with Shakespeare at the Craiova Festival. New Theatre Quarterly 28 (2012): 4: 352-362.

SHEVTSOVA, Maria. 2013. NTQ Reports and Announcements. New Theatre Quarterly 29 (2013): 2: 394-398.

SHEVTSOVA, Maria. 2014. Shakespeare in Gyula. New Theatre Quarterly 30 (2014): 4: 397-402.

SHEVTSOVA, Maria. 2016. The Craiova Shakespeare Festival 2016 and a Valediction for Yukio Ninagawa. New Theatre Quarterly 32 (2016): 3: 276-282.

SULLIVAN, Erin. 2013. Olympic Performance in the Year of Shakespeare. In Paul Edmondson, Paul Prescott and Erin Sullivan (eds.). A Year of Shakespeare: Re-living the World Shakespeare Festival. London: Bloomsbury, 2013: 3-11.

UNGARN-TV. 2018. Heute beginnt das Shakespeare Festival in Gyula (9. 07. 2018). [accessed 24.01.2021]. Available online at https://www.ungarn-tv.com/heute-beginnt-das-shakespearefestival-in-gyula-15870.html.

VALLS-RUSSELL, Janice and Magali ABELLA. 2009. The Theatrum Gedanense Foundation \& Gdańsk's Shakespeare Festival: An Interview with Jerzy Limon. Cahiers Élisabéthains 75 (2009): 1: 59-66.

WILD, Jana. 2020. Personal email correspondence with the author (14. 09. 2020). 


\section{Professor Nicoleta Cinpoeş}

School of Humanities, University of Worcester

Henwick Grove, WR2 6AJ Worcester, UK

n.cinpoes@worc.ac.uk

ORCID: https://orcid.org/0000-0002-2035-9964

Nicoleta Cinpoeş is a UK-based theatre historian and Professor of Shakespeare Studies at the University of Worcester. She is the author of Hamlet in Romania 1778-2008 (2010) as well as editor and contributor to Doing Kyd (2016), Europe's Shakespeare(s) (2018), and Viewing \& Reviewing (2019). She writes regularly for Shakespeare journals and specialist collections. 
